\title{
Jurist-Diction
}

Volume 2 No. 6, November 2019

Histori artikel: Submit 2 September 2019; Diterima 2 Oktober 2019; Diterbitkan online 1 November 2019.

\section{Perlindungan Hukum Bagi Tenaga Kerja Asing Yang Mengalami Kecelakaan Kerja}

\author{
Ervinna Issabella Christanty \\ issabellaervinna@gmail.com \\ Universitas Airlangga
}

\begin{abstract}
Foreign Workers are foreign nationals holding visa with the intention of working in the territory of Indonesia. The purpose of this paper is to find outwhether the company must include foreign workers in BPJS work accident insurance, and how legal sanctions for companies that do not include Foreign Workers in BPJS work accident insurance. The research method used in this study is normative juridical research. Everyone, including foreigners who work for a minimum of 6 (six) months in Indonesia, must be a participant in the social security program according to Article 14 of Act Number 24 of 2011 concerning the Social Security Organizing Agency. what is meant by social security participants according to Article 1 paragraph (4) of Law Number 24 of 2011 concerning the Social Security Organizing Agency is every person, including foreigners who work for at least 6 (six) months in Indonesia who have paid contributions. If the company does not include Foreign Workers in workplace accidents BPJS can be subject to civil sanctions in the form of resolving violations through bipartite negotiations by deliberation to reach consensus, then settlement through mediation, settlement through conciliation, and settlement through arbitration. Administrative sanctions according to Article 17 paragraph (2) of Law Number 24 Year 2011 concerning the Social Security Organizing Agency in the form of: written warning; fine; and / or not getting certain public services etc. And criminal sanctions in the form of imprisonment of a maximum of 8 (eight) years or a criminal fine of at most Rp. 1,000,000,000.00 (one billion rupiah) in Article 55 of Act Number 24 of 2014 concerning the Social Security Organizing Agency.
\end{abstract}

Keywords: Foreign Workers; Work Accidents; Legal Protection; Social Security Organizing Agency.

\begin{abstract}
Abstrak
Tenaga KerjaAsing adalah warga negara asing pemegang visa dengan maksud bekerja di wilayah Indonesia. Adapun tujuan dari skripsi ini yaitu untuk mengetahui apakah perusahaan wajib mengikutsertakan Tenaga Kerja Asing dalam jaminan kecelakaan kerja BPJS, serta bagaimana sanksi hukum bagi perusahaan yang tidak mengikutsertakan Tenaga Kerja Asing dalam jaminan kecelakaan kerja BPJS. Metode penelitian yang digunakan dalam penelitian ini yaitu penelitian yuridis normatif. Setiap orang, termasuk orang asing yang bekerja paling singkat 6 (enam) bulan di Indonesia, wajib menjadi peserta program jaminan sosial menurut Pasal 14 Undang-undang Nomor 24 Tahun 2011 Tentang Badan Penyelenggara Jaminan Sosial, yang dimaksud peserta jaminan sosial menurut Pasal 1 angka (4) Undang-undang Nomor 24 Tahun 2011 Tentang Badan Penyelenggara Jaminan Sosial adalah setiap orang, termasuk orang asing yang bekerja paling singkat 6 (enam) bulan di Indonesia yang telah membayar iuran. Apabila perusahaan tidak mengikut sertakan Tenaga Kerja Asing dalam kecelakaan kerja BPJS dapat dikenakan sanksi perdata berupa penyelesaian pelanggaran melalui perundingan bipartit secara musyawarah untuk mencapai mufakat, lalu penyelesaian melalui mediasi, penyelesaian melalui konsiliasi, dan penyelesaian melalui arbitrase. Sanksi administrasi menurut Pasal 17 ayat (2) Undang-undang Nomor 24 Tahun 2011 Tentang Badan Penyelenggara Jaminan Sosial berupa: teguran tertulis; denda; dan/atau tidak mendapat pelayanan publik tertentu, dan lain-lain. Serta sanksi pidana berupa pidanapenjara paling lama 8 (delapan) tahun atau pidana denda paling banyak Rp. 1.000.000.000,00 (satu miliar rupiah) dalam Pasal 55 Undangundang Nomor 24 Tahun 2014 Tentang Badan Penyelenggara Jaminan Sosial.
\end{abstract}

Kata Kunci: Tenaga Kerja Asing; Kecelakaan Kerja; Perlindungan Hukum; Badan Penyelenggara Jaminan Sosial. 


\section{Pendahuluan}

Tipe penelitian ini menggunakan tipe penelitian yuridis normatif. Tipe penulisan yuridis normatif yaitu pendekatan masalah yang mengkaji perundangundangan dan peraturan yang berkaitan dengan buku buku kepustakaan dan dokumentasi yang berhubungan dengan permasalahan yang menjadi pokok pembahasan yang dibahas dalam penulisan skripsi ini. ${ }^{1}$ Tenaga Kerja Asing sendiri sebenarnya diperlukan agar meningkatkan perekonomian dan dari Tenaga Kerja Asing sendiri Indonesia dapat belajar untuk menggunakan teknologi yang lebih maju untuk keberlangsungan pengetahuan warga Indonesia, tentu pula harus diimbangi dengan adanya persyaratan atau ketentuan guna batasan untuk negara sendiri. Dengan demikian pemerintah Indonesia harus bertindak untuk membentuk peraturan-peraturan terkait Tenaga Kerja Asing guna memberikan pengawasan langsung untuk dampak positif serta kemajuan bagi negara, adanya peraturan tersebut untuk mengawasi terkait penggunaan Tenaga Kerja Asing agar dapat terkendali. Sebagian besar masyarakat Indonesia merupakan seorang pekerja, mulai pekerjaan yang diusahakan sendiri maupun bekerja dengan orang lain. Pekerjaan yang diusahakan sendiri artinya bekerja atas usaha modal dan tanggung jawab sendiri. Sedangkan yang dimaksud bekerja pada orang lain adalah bekerja dengan bergantung dengan orang lain, yang memberi perintah dan mengutusnya, karena ia harus tunduk dan patuh pada orang lain yang memberikan pekerjaan tersebut. ${ }^{2}$ Perlindungan ini dibutuhkan agar menurunkan kasus kecelakan kerja yang terjadi untuk para pekerja. Jika Indonesia memperluas lapangan kerja untuk Tenaga Kerja Asing, maka diperlukan perlindungan keselamatan kerja bagi para pekerja asing tersebut melihat kasus kecelakaan kerja yang mengalami peningkatan sepanjang tahun 2017 sekitar 20\% dibandingkan 2016 secara nasional. ${ }^{3}$

\footnotetext{
1 Peter Mahmud Marzuki, Penelitian Hukum (Kencana Prenada Media 2010).[35].

2 Zainal Asikin, Dasar-Dasar Hukum Perburuhan cetakan keempat (RajaGrafindo Persada 2002).[1].

3 Angka Kecelakaan Kerja RI Meningkat ke 123 Ribu Kasus di 2017 (6 Februari 2019)

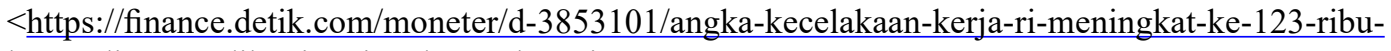
kasus-di-2017, dikunjungi pada 6 Februari 2019
} 
Seperti halnya kasus yang berlokasi di Desa Tanjungpasir, Kec. Pangkalansusu, Kab. Langkat, di mega proyek PTPLN(Persero) PLTU Unit III dan IV, bahwa seorang Tenaga Kerja Asing atas nama Yong Pei Tao berumur 28 Tahun tewas mengenaskan akibat kecelaakaan di lokasi kerja yang diketahui sebelumnya saat bertugas sebagai pengontrol dan mengecek panel-panel yang telah terpasang korban disebut-sebut tersetrum arus listrik di lokasi kerja, kematian Tenaga Kerja Asing Yong Pei Tao ini menambah daftar kecelakaan kerja di perusahaan pembangkit listrik tersebut, saat Public Relations Sinohydro Corporation Limited dimintai keterangannya juga tidak ingin menjawab dengan beralasan bahwa perusahaan tersebut menyangkut orang asing, disini tidak ada kejelasan bagaimana pertanggungjawaban pihak perusahaan untuk kecelakaan tersebut, perusahaan juga diharapkan untuk mengikuti program BPJS ketenagakerjaan agar jika ada kecelakaan kerja perusahaan dapat mengetahui apa saja pertanggungjawabanya terkait jaminan sosial jika terjadi kecelakaan kerja. Sebagai pekerja maka tidak akan lepas dari keselamatan kerja, dengan adanya jaminan keselamatan kerja maka akan membuat para pekerja akan merasa aman. Perusahan memegang peranan penting dalam meningkatkan kualitas keselamatan kerja para pekerja tersebut agar dapat meningkatkan pula kinerja para tenaga kerja tersebut, perusahaan juga diharapkan untuk mengikuti program BPJS ketenagakerjaan agar jika ada kecelakaan kerja perusahaan dapat mengetahui apa saja pertanggungjawabanya terkait jaminan sosial jika terjadi kecelakaan kerja. Serta berdasarkan data BPJS Ketenagakerjaan terdapat 157.313 kasus kecelakaan kerja dalam tahun 2018. ${ }^{4}$ Dalam Pasal 25 Peraturan Presiden Nomor 20 Tahun 2018 Tentang Penggunaan Tenaga Kerja Asing bahwa setiap pemberi kerja Tenaga Kerja Asing wajib menjamin Tenaga Kerja Asing terdaftar dalam jaminan sosial ketenagakerjaan bagi Tenaga Kerja Asing yang bekerja lebih dari 6 (enam) bulan dan/atau polis asuransi di perusahaan asuransi, maka dalam hal ini meskipun pekerja tersebut adalah Tenaga Kerja Asing akan tetapi pemberi kerja wajib

\footnotetext{
${ }^{4}$ Sepanjang 2018, BPJS Catat Ada 157.131 Kasus Kecelelakaan Kerja (15 Januari 2019) $<$ https://www.jawapos.com/nasional/humaniora/15/01/2019/sepanjang-2018-bpjs-catat-ada157313-kasus-kecelakaan-kerja, dikunjungi pada 21 Februai 2019
} 
mengikut sertakan dalam jaminan sosial BPJS tersebut, juga Manusia selalu tidak ada kepastian dalam hidupnya yang dapat menimbulkan kerugian ataupun resiko yang akan dihadapinya maka perlu adanya perlindungan-perlindungan yang dapat memberikan efek aman terhadap para pekerja. Sadar akan pentingnya pekerja untuk sebuah perusahaan, masyarakat, ataupun pemerintah maka perlu adanya pemikiran untuk menjaga keselamatan dalam menjalankan suatu pekerjaan itu.

Berdasarkan pada pemaparan dan uraian masalah diatas, maka dapat diambil rumusan permasalahan antara lain sebagai berikut:

1. Apakah perusahaan wajib mengikut sertakan Tenaga Kerja Asing dalam jaminan kecelakaan kerja BPJS ?

2. Apa sanksi hukum terhadap perusahaan yang tidak mengikut sertakan Tenaga Kerja Asing dalam jaminan kecelakaan kerja BPJS ?

\section{Penggunaan Tenaga Kerja Asing Di Perusahaan}

Perusahaan atau pemberi kerja terhadap Tenaga Kerja Asing sendiri tidak dapat dihindari karena pengalaman kerja yang baik serta maju juga ahli dalam bidangnya maka sangat dibutuhkan untuk kemajuan perekonomian di perusahaan tersebut,umumnya Tenaga Kerja Asing masuk ini atas permintaan perusahaan itu sendiri sebagai upaya agar dapat menghadapi kemajuan global serta persaingan usaha yang semakin ketat, serta untuk memenuhi kebutuhan tenaga kerja yang professional dalam bidang-bidang tertentu yang belum dapat dicapai oleh Tenaga Kerja di Indonesia.

Tenaga Kerja Asing dalam Pasal 1 angka 13 Undang-undang Nomor 13 Tahun 2003 Tentang Ketenagakerjaan, yaitu Tenaga Kerja Asing adalah warga negara asing pemegang visa dengan maksud bekerja di wilayah Indonesia. Tenaga Kerja Asing sendiri harus patuh terhadap Undang-undang Nomor 13 Tahun 2003 Tentang Ketenagakerjaan yang mengatur tentang TKA yang bekerja dalam wilayah Indonesia. Penggunaan Tenaga Kerja Asing harus melalui rencana biasa disebut dengan Rencana Penggunaan Tenaga Kerja Asing atau disingkat RPTKA menurut Pasal 1 angka 4 Peraturan Presiden Nomor 20 Tahun 2018 Tentang 
Penggunaan Tenaga Kerja Asing bahwa Rencana Penggunaan Tenaga Kerja Asing yang selanjutnya disingkat RPTKA adalah rencana penggunaan TKA pada jabatan tertentu yang dibuat oleh Pemberi Kerja TKA untuk jangka waktu tertentu yang disahkan oleh menteri yang membidangi urusan pemerintahan di bidang ketenagakerjaan atau pejabat yang di tunjuk. Dalam Pasal 6 Undang-undang Nomor 13 Tahun 2003 Tentang Ketenagakerjaan bahwa setiap pekerja/buruh berhak memperoleh perlakuan yang sama tanpa diskriminasi dari perusahaan, yang berkaitan dengan pengupahan dalam Pasal 88 Undang-undang Nomor 13 Tahun 2003 Tentang Ketenagakerjaan bahwa setiap pekerja/buruh berhak memperoleh penghasilan yang memenuhi penghidupan yang layak bagi kemanusiaan, lalu yang berkaitan dengan kesejahteraan dalam Pasal 99 Undang-undang Nomor 13 Tahun 2003 Tentang Ketenagakerjaan bahwa setiap pekerja/buruh dan keluarganya berhak untuk memperoleh jaminan sosial tenaga kerja, serta yang berkaitan dengan keselamatan dan kesehatan dalam Pasal 86 ayat (1) Undang-undang Nomor 13 Tahun 2003 Tentang Ketenagakerjaan bahwa setiap pekerja/buruh mempunyai hak untuk meperoleh perlindungan atas :

a. Keselamatan dan kesehatan kerja;

b. Moral dan kesusilaan; dan

c. Perlakuan yang sesuai dengan harkat dan martabaat manusia serta nilai-nilai agama.

4 (empat) ketentuan tersebut adalah bersifat umum yang berlaku untuk tenaga kerja yaitu Tenaga Kerja Indonesia dan Tenaga Kerja Asing. Pengaturan dalam penggunaan Tenaga kerja Asing dalam Bab VIII ini tidak mengatur khusus untuk hak-hak apa saja yang melekat dengan TKA, sehingga hak Tenaga Kerja Asing prinsipnya adalah hak yang melekat pada Tenaga Kerja Indonesia juga.

Pasal 42 ayat (4) Undang-undang Nomor 13 Tahun 2003 Tentang Ketenagakerjaan bahwa Tenaga Kerja Asing dapat dipekerjakan di Indonesia hanya dalam hubungan kerja untuk jabatan tertentu dan waktu tertentu,dalam Pasal 46 ayat (1) Undang-undang Nomor 13 Tahun 2003 Tentang Ketenagakerjaan bahwa Tenaga Kerja Asing dilarang untuk menduduki jabatan yang mengurusi tentang 
personalia dan/atau jabatan-jabatan tertentu juga ada di Pasal 5 ayat (1) Peraturan Presiden Nomor 20 Tahun 2018 Tentang Penggunaan Tenaga Kerja Asing, dan juga dalam Pasal 7 ayat (1) Peraturan Menteri Ketenagakerjaan Nomor 10 Tahun 2018 Tentang Tata Cara Penggunaan Tenaga Kerja Asing. Tenaga Kerja Indonesia atau Tenaga Kerja Asing yang sama-sama bekerja untuk melakukan pekerjaannya dapat dilindungi oleh hukum.

\section{Ruang Lingkup Jaminan Dalam Badan Penyelenggara Jaminan Sosial}

Badan Penyelenggara Jaminan Sosial (BPJS) atau yang dulu dikenal sebagai PT Jamsostek ini mempunyai sedikit perbedaan dalam pelaksanaannya akan tetapi pengguna Jamsostek tentunya diminta untuk tidak khawatir untuk perubahan tersebut dikarenakan kebijakan dari pemerintah mengarah untuk kemajuan serta kesejahteraan masyarakat. Pekerja pasti memiliki hak untuk mendapatkan perlindungan jika mengalami resiko di tempat kerjanya maka pekerja harus mendapatkan perlakuan yang adil dalam hubungan kerja

BPJS dibentuk sebagai penyelenggara program jaminan sosial dalam Pasal 28 H ayat (3) Undang-undang Dasar Negara Republik Indonesia Tahun 1945 disebutkan bahwa setiap orang berhak atas jaminan sosial yang memungkinkan pengembangan dirinya secara utuh sebagai manusia yang bermartabat. Program BPJS ini dibentuk sebagai pengembang sistem jaminan sosial yang berguna bagi seluruh rakyat. Menurut Pasal 1 angka (1) Undang-Undang Nomor 24 Tahun 2011 tentang Badan Penyelenggara Jaminan Sosial, Badan Penyelenggara Jaminan Sosial (BPJS) ialah badan hukum yang dibentuk guna sebagai penyelenggara program jaminan sosial yang selanjutnya disebut sebagai BPJS. Berdasarkan Undang-Undang Nomor 24 Tahun 2011 Tentang Badan Penyelenggara Jaminan Sosial terdapat 2 (dua) Badan Penyelenggara Jaminan Sosial (BPJS) :

1. BPJS Kesehatan; dan

2. BPJS Ketenagakerjaan.

Berdasarkan Pasal 6 ayat (1) Undang-undang Nomor 24 Tahun 2011 Tentang Badan Penyelenggara Jaminan Sosial, yang dimaksud BPJS Kesehatan adalah 
Badan Penyelenggara Jaminan Sosial yang hanya menyelenggarakan program jaminan kesehatan. Sedangkan BPJS Ketenagakerjaan berdasarkan Pasal 6 ayat (2) Undang Nomor 24 Tahun 2011 Tentang Badan Penyelenggara Jaminan Sosial adalah Badan Penyelenggara Jaminan Sosial yang menyelenggarakan program :
a. jaminan kecelakaan kerja;
b. jaminan hari tua;
c. jaminan pensiun; dan
d. jaminan kematian.

Jaminan sosial sendiri diberikan sebagai perlindungan tenaga kerja sebagai pengganti jika penghasilanya hilang atau bahkan berkurang akibat keadaan yang dialami seperti contohnya sakit, kecelakaan kerja, atau meninggal dunia. ${ }^{5}$ Dengan adanya jaminan sosial maka terdapat perlindungan yang berguna bagi keluarga dan tenaga kerja sendiri.

Jaminan sosial bagi tenaga kerja mempunyai beberapa aspek yaitu: ${ }^{6}$

a. Memberikan perlindungan dasar untuk memenuhi kebutuhan hidup bagi tenaga kerja beserta keluarganya;

b. Merupakan penghargaan kepada tenaga kerja yang telah menyumbangkan tenaga dan pikirannya kepada perusahaan tempat mereka bekerja.

\section{Jaminan Kecelakaan Kerja Bagi Tenaga Kerja Asing}

Kecelakaan kerja ialah kecelakaan yang berhubungan dengan pekerjaanya dalam perusahaan, yang berarti bahwa kecelakaan tersebut terjadi pada saat melaksanakan pekerjaanya ataupun penyakit akibat kerja dengan demikian kecelakaan kerja dapat dikelompokkan: ${ }^{7}$

1. Kecelakaan kerja di perusahaan;

2. Kecelakaan lalu lintas; dan

3. Kecelakaan di rumah.

\footnotetext{
${ }^{5}$ Lanny Ramly, Jaminan Sosial Tenaga Kerja di Indonesia (Airlangga University1997).[ 2].

${ }^{6}$ Zaeni Asyhadie, Aspek-aspek Hukum Jaminan Sosial Tenaga Kerja di Indonesia (Rajawali 2008).[84].

7 Djoko Triyanto, Hubungan Kerja di Perusahaan Jasa Kontruksi(Mandar Maju 2004).[154].
} 
Adanya kecelakaan kerja tersebut maka dibutuhkan jaminan sosial untuk kecelakaan kerja yang penting bagi pekerja/buruh, jaminan kerja tersebut dapat meliputi berbagai hal seperti biaya pemeriksaan. biaya pengangkutan, biaya pengobatan dan perawatan, biaya rehabilitasi serta santunan berupa uang. Jaminan sosial adalah salah satu bentuk perlindungan sosial untuk menjamin seluruh rakyat agar dapat memenuhi kebutuhan dasar hidupnya yang layak pengertian ini menurut Pasal 1 angka (2) Undang-Undang Nomor 24 Tahun 2011 Tentang Badan Penyelenggara Jaminan Sosial, Jaminan sosial memiliki beberaapa aspek: ${ }^{8}$

1. Jaminan sosial memberikan perlindungan untuk memenuhi segala kebutuhan hidup bagi tenaga kerja serta keluarganya.

2. Adanya perlindungan akan memberikan kepastian masuknya pendapatan atau penghasilan sebagai pengganti seluruh penghasilan yang hilang.

3. Jaminan sosoal dapat menciptakan ketenangan atau keamanan dalam bekerja karena adanya perlindungan terhadap risiko sosial serta ekonomi.

4. Dengan adanya perlindungan dan ketenangan serta keamanan kerja akan berdampak dengan produktivitas kerja.

5. Terciptanya ketenangan dan keamanan kerja pada akhirnya dapat mendukung kemandirian manusia dalam mengahadapi sosial ekonomi.

Badan penyelenggara jaminan sosial ini yang akan menjalankan programprogram jaminan sosial kepada rakyat dan harus sesuai dengan Undang-undang hukum kerja atau hukum ketenagakerjaan di bidang hubungan kerja yang pastinya mempunyai semua peraturan perundang-undangan mengenai jaminan sosial yang berlaku bagi seluruh rakyat.

Dengan adanya jaminan kecelakaan kerja ini bagi para Tenaga Kerja sangat diperlukan karena dapat mengatasi atau bahkan menguranggi risiko ekonomis yang ditimbulkan dari kecelakaan kerja yang terjadi kepadanya (pekerja/buruh). Serta dalam Pasal 25 Peraturan Presiden Nomor 20 Tahun 2018 Tentang Penggunaan Tenaga Kerja Asing bahwa setiap pemberi kerja Tenaga Kerja Asing wajib menjamin Tenaga Kerja Asing terdaftar dalam jaminan sosial ketenagakerjaan bagi Tenaga Kerja Asing yang bekerja lebihh dari 6 (enam) bulan dan/atau polis asuransi di perusahaan asuransi. Juga dalam Pasal 14 Undang-undang Nomor 24 Tahun

${ }^{8}$ Pandji Anoraga, Penerapan Jaminan Sosial Di Indonesia (Dunia Pustaka Jaya1995).[55]. 
2011 Tentang Badan Penyelenggara Jaminan Sosial bahwa Setiap orang, termasuk orang asing yang bekerja paling singkat 6 (enam) bulan di Indonesia, wajib menjadi peserta program jaminan sosial.

\section{Jenis-Jenis Sanksi Di Dalam Hubungan Industrial}

Menurut Pasal 1 angka 16 Undang-undang Nomor 13 Tahun 2003 Tentang Ketenagakerjaan bahwa hubungan industrial adalah suatu sistem hubungan yang terbentuk antara pelaku dalam proses produksi barang/jasa yang terdiri dar unsur pengusaha, pekerja/buruh, dan pemerintah yang didasarkan pada nilainilai Pancasila dan Undang-undang Dasar Negara Republik Indonesia Tahun 1945. Hubungan industrial ini berpengaruh terhadap kelangsungan sebuah proses produksi yang terjadi di sebuah perusahaan, keseimbangan antar pekerja serta pengusaha juga penting serta itulah tujuannya yang hendak dicapai yaitu agar lebih harmonis karena hubungan antara pekerja dan perusahaan ini saling mengisi dan saling membutuhkan dalam artian lain para pengusaha tidak akan menghasilkan sesuatu yang menguntungan jika tidak didukung oleh para pekerjannya demikian pula sebaliknya antara pengusaha dan pekerja karena keduanya mempunyai kepentingan yang sama yaitu untuk meningkatkan taraf hidup masing-masing dan untuk mengembangan perusahaan. Fungsi hubungan industrial sendiri adalah fungsi masing-masing pihak yang melaksanakan hubungan industrial yaitu : pemerintah, pekerja/buruh atau serikat, dan pengusaha, fungsi pemerintah dalam melaksanakan hubungan industrial adalah: menetapkan kebijakan; memberikan pelayanan; melaksanakan pengawasan; dan melakukan penindakan terhadap pelanggaran peraturan perundang-undangan ketenagakerjaan peraturan menurut Pasal 102 ayat (1) Undang-undang Nomor 13 Tahun 2003 Tentang Ketenagakerjaan, lalu berdasarkan Pasal 102 ayat (2) Undang-undang Nomor 13 Tahun 2003 Tentang Ketenagakerjaan fungsi pekerja/buruh dan serikat pekerja/serikat buruh dalam melaksanakan hubungan industrial adalah :

1. Menjalankan pekerjaan sesuai dengan kewajibannya;

2. Menjaga ketertiban demi kelangsungan produksi;

3. Menyalurkan aspirasi secara demokratis; 
4. Mengembangkan ketrampilan dan keahliannya serta ikut memajukan perusahaan; dan

5. Memperjuangkan kesejahteraan anggota beserta keluarganya.

Hubungan industrial sendiri berarti pengusaha dan pekerja ada kalanya akan menimbulkan perselisihan hak ataupun pertentangan dalam hubungan pekerjaan, perselisihan hak dalam Pasal 1 angka 2 Undang-undang Nomor 2 Tahun 2004 Tentang Penyelesaian Perselisihan Hubungan Industrial bahwa perselisihan hak adalah perselisihan yang timbul karena tidak dipenuhinya hak, akibat adanya perbedaan pelaksanaan atau penafsiran terhadap ketentuan peraturan perundangundangan, perjanjian kerja, peraturan perusahaan, atau perjanjian kerja bersama. Perselisihan ini bisa saja seperti perbedaan pendapat ataupun konflik lainnya Untuk meminimalisir terjadinya konflik maka perlu adanya komunikasi yang baik untuk dapat mencari solusi dari kedua belah pihak yang mempunyai kepentingan berbeda, atau untuk menyelesaikan perselisihan tersebut diatur dalam Undang-undang Nomor 2 Tahun 2004 Tentang Penyelesaian Perselisihan Hubungan Industrial bahkan mungkin akan membuat tindakan-tindakan yang dilarang oleh hukum maka akan melanggar asas dan jika perusahaan menimbulkan konflik serta tindakan yang dilarang oleh hukum atau melanggar asas maka akan dikenai sanksi-sanksi yang sudah diatur oleh peraturam perundang-undangan. dengan adanya sanksi dapat membuat kelompok ataupun seseorang tersebut menjadi jera dan tidak mengulangi kesalahan yang mereka lakukan maka semakin berat kesalahan yang dilakukan maka sanksi yang diberikan akan semakin berat juga. Sanksi di Indonesia sendiri secara umum dikenal terdapat 3 (tiga) jenis sanksi hukum yaitu : a. sanksi hukum perdata; b. sanksi hukum administasi/administratif;dan c. sanksi hukum pidana.

Hubungan industrial dapat berjalan dengan baik jika kedua belah pihak dapat berjalan bersama untuk mencapai keharmonisan yang inginkan dengan cara samasama merasa ikut memiliki, ikut menjaga, dan mempertahankan serta senantiasa berhati-hati dalam bertindak. Melalui proses bersama itu akan diperoleh juga kesejahteraan para tenaga kerja, untuk memenuhi kesejahteraan tersebut perusahaan juga berusaha untuk dapat terus melakukan upaya serta program-program untuk mewujudkan, memelihara, memulihkan dan dapat mengembangkan kesejahteraan 
didalam hubungan industrial dapat berupa jaminan sosial, upah, serta kesehatan dan keselamatan para pekerja/buruh, kalaupun ada perselisihan antara perusahaan dan pekerja akan dapat diselesaikan dengan cara musyawarah ataupun dapat melalui prosedur yang diatur dalam peraturan perundang-undangan dan pada akhirnya dapat mencapai pertumbuhan ekonomi dan hubungan industrial yang tentram serta harmonis, dengan demikian mengenai perlindungan bagi pekerja untuk pelaksanaan hubungan industrial yang sudah diatur dalam Undang-undang Nomor 13 Tahun 2003 Tentang Ketenagakerjaan dan dalam Undang-undang Nomor 2 Tahun 2004 Tentang Penyelesaian Perselisihan Hubungan Industrial mengenai perlindungan serta kepastian hukum untuk penyelesaian perselisihan hubungan industrial.

\section{Penyelesaian Perselisihan Di Dalam Hubungan Industrial Terkait Tidak Diikutsertakanya Tenaga Kerja Asing Dalam Jaminan Kecelakaan Kerja}

Perselisihan hubungan industrial ini semakin rumit dan kompleks maka dalam hal ini diperlukan adanya pengadilan khusus untuk memutus serta mengadili perselisihan hubungan industrial tersebut. Dengan adanya Undang-undang Nomor 2 Tahun 2004 Tentang Penyelesaian Perselisihan Hubungan Indutrial (UUPPHI) yang telah dibentuk, dengan undang-undang tersebut dibentuklah pengadilan khusus yang telah diberi nama Pengadilan Hubungan Industrial. Melihat kurang baiknya pelaksanaan hubungan industrial dengan jaminan sosial pekerja di dalam sebuah perusahaan yang membuat lemahnya perlindungan terhadap pekerja tersebut baik oleh pengusaha ataupun oleh pemerintah dalam hal ini akan menghambat kinerja perusahaan di Indonesia sendiri sangat memprihatinkan jika menyangkut masalah ketenagakerjaan, berkurangnya keharmonisan hubungan industrial dan rendahnya jaminan sosial yang diberikan bagi pekerja dan masih lemahnya perlindungan yang diberikan untuk tenaga kerja, jika ada perselisihan di dalam hubungan industrial tersebut dapat diselesaikan dengan beberapa cara. Perselisihan hak ini terjadi karena salah satu pihak tidak bisa melaksanakan atau adanya perbedaan penafsiran terhadap suatu aturan, baik aturan perundang-undangan atau peraturan perusahaan serta hak yang timbul dari suatu perjanjian.Menurut hukum perdata 
apabila salah satu pihak melanggar aturan hukum (tidak melaksanakan kewajiban yang diatur oleh hukum), menyebabkan hilangnya hak orang lain. Maka perbuatan itu dapat dikualifikasi sebagai perbuatan melanggar hukum. Sedangkan apabila salah satupihak tidak memenuhi kewajiban sebagaimana telah diatur dalam perjanjian maka perbuatan itudapat dikualifikasi sebagai perbuatan "ingkarjanji” ataupun wanprestasi. Penyelesaian kedua pelanggaran itu dapat dilakukan secara musyawarah (non litigasi/ di luar peradilan). Atau dengan cara mengajukan gugatan di Pengadilan(litigasi)

Adapun penyelesaian perselisihan yang dikenal dengan perselisihan hak menurut Undang-undang Nomor 2 Tahun 2004. PadaPasal 3 ayat 1 Undangundang Nomor 2 Tahun 2004 Tentang Penyelesaian Perselisihan Hubungan Industrial ditegaskan bahwa Perselisihan hubungan industrial wajib diupayakan penyelesaiannya terlebih dahulu melalui perundingan bipartit secara musyawarah untuk mencapai mufakat. Penyelesaian perselisihan di Indonesia dapat dilakukan dan memilih salah satu diantaranya ialah: 1. penyelesaian melalui bipartit 2 . penyelesaian melalui mediasi 3. penyelesaian melalui konsilisasi 4. penyelesaian melalui arbritase apabila penyelesaian tersebut tidak bisa dilakukan maka dilakuan gugatan ke pengadilan hubungan industrial untuk melaksanakan kewajibanya.

\section{Sanksi Administrasi Terhadap Perusahaan Yang Tidak Mengikutsertakan Tenaga Kerja Asing Dalam Jaminan Kecelakaan BPJS}

Perusahaan wajib mengikutsertakan setiap pekerja pada program Jaminan Sosial Tenaga Kerja BPJS, karena hal tersebut merupakan hak setiap tenaga kerja, baik dalam hubungan kerja, Pasal 25 Peraturan Presiden Nomor 20 Tahun 2018 Tentang Penggunaan Tenaga Kerja Asing, bahwa setiap pemberi kerja Tenaga Kerja Asing wajib menjamin Tenaga Kerja Asing terdaftar dalam jaminan sosial ketenagakerjaan bagi Tenaga Kerja Asing yang bekerja lebih dari 6 (enam) bulan dan/ atau polis asuransi di perusahaan asuransi, oleh karena itu program BPJS tersebut wajib dilakukan oleh setiap pemberi kerja/atau perusahaan. Jika perusahaan tidak mengikut sertakaan Tenaga Kerja Asing dalam program jaminan kecelakaan BPJS 
akan dikenakan sanksi administratif. adapun sanksi administratif yang dimaksud ialah dalam Pasal 17 ayat (2) Undang-undang Nomor 24 Tahun 2011 Tentang Badan Penyelenggara Jaminan Sosial, Sanksi administratif sebagaimana dimaksud pada ayat (1) dapat berupa:

a. teguran tertulis;

b. denda; dan/atau

c. tidak mendapat pelayanan publik tertentu.

Pengenaan sanksi berupa teguran tertulis dan denda dilakukan oleh BPJS sebagaimana diatur dalam Pasal 17 ayat (3) Undang-undang Nomor 24 Tahun 2011 Tentang Badan Penyelenggara Jaminan Sosial. Peraturan-peraturan terkait wajibnya perusahaan agar mendaftarkan dirinya dan pekerjanya juga tertuang dalam Pasal 3 ayat (1) Peraturan Pemerintah Nomor 86 Tahun 2013TentangTata Cara Pengenaan Sanksi Administratif Kepada Pemberi Kerja SelainPenyelenggara Negara Dan Setiap Orang, Selain Pemberi Kerja, Pekerja, DanPenerima Bantuan Iuran Dalam Penyelenggaraan Jaminan Sosial, bahwa Pemberi Kerja Selain Penyelenggara Negara wajib:

a. mendaftarkan dirinya dan pekerjanya sebagai peserta kepada BPJS secara bertahap sesuaidengan program jaminan sosial yang diikutinya; dan

b. memberikan data dirinya dan pekerjanya berikut anggota keluarganya kepadaBPJS secaralengkap dan benar.

Maka sanksi administrasi juga dapat dikenakan kepada perusahaan atau pemberi kerja dalam Pasal 5 ayat (1) Peraturan Pemerintah Nomor 86 Tahun 2013TentangTata Cara Pengenaan Sanksi Administratif Kepada Pemberi Kerja SelainPenyelenggara Negara Dan Setiap Orang, Selain Pemberi Kerja, Pekerja, dan Penerima Bantuan Iuran Dalam Penyelenggaraan Jaminan Sosial, bahwa pemberi kerja selain penyelenggara negara yang melanggar ketentuan sebagaimana dimaksud dalam Pasal 3 dan setiap orang, selain pemberi kerja, pekerja, dan penerima bantuan iuran yang melanggar ketentuan sebagaimana dimaksud dalam Pasal 4 dikenai sanksi administrasi. Juga sanksi yang dapat diberikan unuk pemberi kerja adalah dalam Pasal 9 ayat (1) Peraturan Pemerintah Nomor 86 Tahun 2013 TentangTata Cara Pengenaan Sanksi 
Administratif Kepada Pemberi Kerja Selain Penyelenggara Negara Dan Setiap Orang, Selain Pemberi Kerja, Pekerja, dan Penerima Bantuan Iuran Dalam Penyelenggaraan Jaminan Sosial. bahwa pemberi kerja selain penyelenggara negara yang melanggar ketentuan sebagaimana dimaksud dalam Pasal 3 dan setiap orang, selain pemberi kerja, pekerja, dan penerima bantuan iuran yang melanggarketentuan sebagaimana dimaksud dalam Pasal 4 dikenai sanksi administrasi. Juga sanksi yang dapat diberikan unuk pemberi kerja adalah dalam Pasal 9 ayat (1) Peraturan Pemerintah Nomor 86 Tahun 2013TentangTata Cara Pengenaan Sanksi Administratif Kepada Pemberi Kerja Selain Penyelenggara Negara Dan Setiap Orang, Selain Pemberi Kerja, Pekerja, dan Penerima Bantuan Iuran Dalam Penyelenggaraan Jaminan Sosial, bahwa sanksi tidak mendapat pelayanan publik tertentu yang dikenal kepada pemberi kerja selain penyelenggara negara meliputi:

a. Perizinan terkait usaha;

b. Izin yang diperlukan dalam mengikuti tender proyek;

c. Izin mmpekerjakan tenaga kerja asing;

d. Izin perusahaan penyedia jasa pekerja/buruh; atau

e. Izin mendirikan bangungan (IMB)

Inilah sanksi administrasi yang dapat diberikan kepada perusahaan jika tidak mengikut sertakan tenaga kerja dalam jaminan sosial kecelakaan kerja BPJS.

\section{Sanksi Pidana Terhadap Perusahaan Yang Tidak Mengikutsertakan Tenaga Kerja Asing Dalam Jaminan Kecelakaan Kerja Bpjs}

Kewajiban perusahaan untuk mendaftarkan Tenaga Kerja Asing harus dijalanan untuk pemenuhan hak-hak bagi Tenaga Kerja Asing juga kewajiban yang memang harus dilaksanakan oleh sebuah perusahaan dalam pemenuhan jaminan sosial kecelakaan kerja BPJS karena banyaknya kasus kecelakaan kerja di Indonesia maka perlindungan serta mengikutsertakan tenaga kerja tersebut sangatlah penting. Dan dalam Pasal 14 Undang-undang Nomor 24 Tahun 2014 Tentang Badan Penyelenggara Jaminan Sosial bahwa setiap orang termasuk orang asing yang bekerja paling singkat 6 (enam) bulan di Indonesia wajib menjadi peserta program jaminan sosial. Dan dalam hal ini pemberi kerja secara bertahap wajib 
mendaftarkan dirinya dan pekerjannyya sebagai peserta kepada BPJS sesuai dengan program jaminan sosial yang diikuti Pasal 15 ayat (1) Undang-undang Nomor 24 Tahun 2014 Tentang Badan Penyelenggara Jaminan Sosial, disini pemberi kerja juga mempunyai kewajiban untuk memungut iuran yang menjadi beban peserta dari pekerjaanya dan menyetorkanya kepada BPJS sebagaimana diatur dalam Pasal 19 ayat (1) dan (2) Undang-undang Nomor 24 Tahun 2014 Tentang Badan Penyelenggara Jaminan Sosial, apabila sanksi administrasi telah dilakuan tapi jika perusahaan tak juga mengikutsertakan para pekerjanya di BPJS Ketenagakerjaan dan tidak mematuhi ketentuan dalam Pasal 19 ayat (1) dan (2) Undang-undang Nomor 24 Tahun 2014 Tentang Badan Penyelenggara Jaminan Sosial maka dapat di pidana penjara paling lama 8 (delapan) tahun atau pidana denda paling banyak Rp. 1.000.000.000,00 (satu miliar rupiah) dalam Pasal 55 Undang-undang Nomor 24 Tahun 2014 Tentang Badan Penyelenggara Jaminan Sosial.

Penjelasan singkatnya bahwa pidana penjara hukumanya diancam dengan pidana sekurangnya adalah 1 (satu) hari dan selama-lamanya ialah 15 (lima belas) tahun sedangkan sanksi pidana denda hukumanya dngan membayar sejmlah uang. Sanksi pidana ini penting untuk memberikan efek jera agar perusahaan dapat menjalankan hak yang seharusnya diperoleh Tenaga Kerja Asing tentang jaminan sosial kecelakaan kerja itu dan tentunya bukan hanya untuk Tenaga Kerja tersebut tapi juga untuk anggota keluarganya apabila tenaga kerja tersebut mengalami kecelakaan kerja yang mengakibatkan meninggal dunia. Dengan adanya jaminan sosial tersebut dapat membantu biaya-biaya untuk keberlangsungan hidup keluarga yang ditinggalkan oleh Tenaga Kerja Asing tersebut.

\section{Kesimpulan}

Bahwa pemberi kerja/perusahaan wajib mendaftarkan Tenaga Kerja Asing dalam program jaminan kecelakaan kerja BPJS menurut Pasal 25 Peraturan Presiden Nomor 20 Tahun 2018 Tentang Penggunaan Tenaga Kerja Asing bahwa setiap pemberi kerja Tenaga Kerja Asing wajib menjamin Tenaga Kerja Asing terdaftar dalam jaminan sosial ketenagakerjaan bagi Tenaga Kerja Asing yang bekerja 
lebih dari 6 (enam) bulan dan/atau polis asuransi di perusahaan asuransi. Bahwa sanksi yang dapat diberikan adalah 1) sanksi perdata jika terjadi perselisihan antara kedua belah pihak maka dapat melalui proses musyawarah terlebih dahulu atau memilih salah satu penyelesaian perselisihan tersebut namun apabila tidak bisa juga melalui musyawarah maka dapat mengajukan gugatan ke Pengadilan Hubungan Industrial untuk perusahaan melaksanakan kewajibanya untuk mengganti segala kerugian yang diderita oleh TKA tersebut. 2) sanksi administrasi dalam pasal 15 ayat (1) Undang-undang Nomor 24 Tahun 2014 Tentang Badan Penyelenggara Jaminan Sosial tentang kewajiban perusahaan untuk mendaftarkan dirinya dan pekerjanya dalam jaminan sosial BPJS dan apabila dalam Pasal 15 ayat (1) tersebut tidak dilaksanakan maka akan dikenai sanksi administrasi dalam Pasal 17 ayat (2) Undang-undang Nomor 24 Tahun 2014 Tentang Badan Penyelenggara Jaminan Sosial a. teguran tertulis; b. denda; dan/atau c. tidak mendapat pelayanan publik tertentu. Pengenaan sanksi di dalam huruf a dan b dilakukan oleh BPJS sedangkan yang c dilakukan oleh pemerintah atau pemerintah daerah atas permintaan BPJS ini dalam pasal 17 ayat (3) dan (4) Undang-undang Nomor 24 Tahun 2014 Tentang Badan Penyelenggara Jaminan Sosial. 3) sanksi pidana yang dapat diberikan untuk perusahaan adalah dapat di pidana penjara paling lama 8 (delapan) tahun atau pidana denda paling banyak Rp. 1.000.000.000,00 (satu miliar rupiah) dalam Pasal 55 Undang-undang Nomor 24 Tahun 2014 Tentang Badan Penyelenggara Jaminan Sosial. Adapun yang dapat memberikan sanksi ini adalah Pengadilan Negeri.

\section{Daftar Bacaan}

\section{Buku}

Djoko Triyanto, Hubungan Kerja di Perusahaan Jasa Kontruksi(Mandar Maju 2004).

Lanny Ramly, Jaminan Sosial Tenaga Kerja di Indonesia(Airlangga University 1997).

Peter Mahmud Marzuki, Penelitian Hukum(Kencana Prenada Media 2010).

Zaeni Asyhadie, Aspek-aspek Hukum Jaminan Sosial Tenaga Kerja di 
Indonesia(Rajawali 2008).

Zainal Asikin, Dasar-Dasar Hukum Perburuhan cetakan keempat(RajaGrafindo Persada 2002).

\section{Laman}

Prins David Saut, 'Angka Kecelakaan Kerja RI Meningkat ke 123 Ribu Kasus di2017' (6 Februari 2019) <https://finance.detik.com/moneter/d-3853101/angkakecelakaan-kerja-ri-meningkat-ke-123-ribu-kasus-di-2017, dikunjungi pada 6 Februari 2019.

YesikaDinta, 'Sepanjang 2018BPJSCatatAda 157.131 Kasus KecelelakaanKerja'(15 Januari 2019) <https://www.jawapos.com/nasional/humaniora/15/01/2019/ sepanjang-2018-bpjs-catat-ada-157313-kasus-kecelakaan-kerja, dikunjungi pada 21 Februai 2019.

\section{Perundang-undangan}

Undang-Undang Dasar Negara Republik Indonesia Tahun 1945.

Undang-Undang Nomor 13 Tahun 2003 Tentang Ketenagakerjaan (Lembaran Negara Republik Indonesia Tahun 2003 Nomor 39; Tambahan Lembaran Negara Nomor 4279).

Undang-Undang Nomor 2 Tahun 2004 Tentang Penyelesaian Perselisihan Hubungan Industrial (Lembaran Negara Republik Indonesia Tahun 2004 Nomor 6; Tambahan Lembaran Negara Nomor 4356).

Undang-Undang Nomor 6 Tahun 2011 Tentang Keimigrasian (Lembaran Negara Republik Indonesia Tahun 2011 Nomor 52; Tambahan Lembaran Negara Nomor 5216 ).

Undang-Undang Nomor 24 Tahun 2011 Tentang Badan Penyelenggara Jaminan Sosial (Lembaran Negara Republik Indonesia Tahun 2011 Nomor 116, Tambahan Lembaran Negara Republik Indonesia Nomor 5256).

Peraturan Presiden Republik Indonesia Nomor 20 Tahun 2018 Tentang Penggunaan Tenaga Kerja Asing.

Peraturan Pemerintah Nomor 86 Tahun 2013 Tentang Tata Cara Pengenaan Sanksi Administratif Kepada Pemberi Kerja Selain Penyelenggara Negara dan Setiap Orang, Selain Pemberi Kerja, Pekerja, Dan Penerima Bantuan Iuran Dalam Penyelenggaraan Jaminan Sosial. 
Peraturan Pemerintah Republik Indonesia Nomor 44 Tahun 2015 Tentang Penyelenggaraan Program Jaminan Kecelakaan Kerja dan Jaminan Kematian.

Peraturan Pemerintah Republik Indonesia Nomor 46 Tahun 2015 Tentang Penyelenggaraan Program Jaminan Hari Tua.

Peraturan Pemerintah Republik Indonesia Nomor 45 Tahun 2015 Tentang Penyelenggaraan Program Jaminan Pensiun.

Peraturan Menteri Ketenagakerjaan Nomor 10 Tahun 2018 Tentang Tata Cara Penggunaan Tenaga Kerja Asing.

HOW TO CITE: Ervinna Issabella Christanty, 'Perlindungan Hukum Bagi Tenaga Kerja Asing Yang Mengalami Kecelakaan Kerja' (2019) Vol. 2 No. 6 Jurist-Diction. 